\title{
Seabird reproduction in an unpredictable environment: how King penguins provide their young chicks with food
}

\author{
Michel Gauthier-Clerc*, Yvon Le Maho, Yannick Clerquin, Charles-André Bost, \\ Yves Handrich
}

Centre d'Écologie et Physiologie Énergétiques, CNRS, 23 rue Becquerel, 67087 Strasbourg cedex 2, France

\begin{abstract}
Pelagic seabirds depend on resources far out at sea and for which the availability can vary greatly. King penguins rely essentially on myctophid fish, which in summer are mostly available 400 to $500 \mathrm{~km}$ south of the Crozet Archipelago at the Antarctic Polar Front. Incubating male King penguins anticipate a possible delay in the return of the female by storing food in their stomach for several weeks, which enables them to feed the chick quickly if hatching occurs. We investigated the foraging trip duration, adult body mass regulation and the meal size for chicks relative to the laying date and the Polar Front position. We compared, in both early and late breeders, the energy content and the chemical and diet composition of the meals stored in their stomachs. During food storage by the male, the cessation of digestive processes was not complete as the meal showed some modifications of the biochemical composition, especially a decrease in lipid content; this is in contrast to oil storage in albatrosses and petrels, in which there is an increase in lipid content. On average, females came back from their second foraging trip at sea a short time before hatching. However, the trip durations were particularly variable depending on date and year, and as a consequence hatching occurred with either the female or the male incubating the egg. Late breeders showed longer foraging trip duration and built up larger fuel reserves than early breeders. Their energetic output per day foraging at sea was much lower than for early breeders. These differences in foraging trip durations of males were linked to a change in marine resource availability because, in spite of being at the same stage of the breeding cycle, male late breeders caught different prey compared to male early breeders. We assume that this strategy of long-term food storage and conservation in the stomach while fasting evolved in response to the unpredictable variations of water mass positions.
\end{abstract}

KEY WORDS: Pelagic seabird · Food provisioning · Foraging trip · Polar Front - Diet composition · Crozet $\cdot$ Ecophysiology

Resale or republication not permitted without written consent of the publisher

\section{INTRODUCTION}

Environmental constraints prevent most animals from adjusting day-to-day food intake with energy expenditure. To overcome this they accumulate stores of nutritive material in their body tissues, primarily as

${ }^{*}$ Present address: Station Biologique de la Tour du Valat, Le Sambuc, 13200 Arles, France.

E-mail: michel.gauthier-clerc@wanadoo.fr fat and carbohydrates. In addition to an animal's own need, adults may have to procure energy for their offspring. Several ways of delivering energy to the offspring have evolved. One consists of a complete assimilation and storage in the body tissues before being delivered in the form of a secretion, as is the case for mammalian milks or the oesophageal secretion of the Emperor penguin (Prévost 1961). A widespread solution consists in carrying directly fresh or predigested food, using anatomical cavities such as the crop or 
stomach to temporarily store the food. In procellariiforms, i.e. albatrosses and petrels, the assimilation of ingested food is only partial, with proteins being digested and the more energy-rich lipids stored as oils in the stomach before delivery by regurgitation to the chick (Warham et al. 1976).

Pelagic birds depend on resources several 10s to several $1000 \mathrm{~s}$ of $\mathrm{km}$ out at sea, and for which the availability can vary greatly (Hunt \& Schneider 1987). Three main constraints on chick feeding by adult pelagic seabirds have been suggested to be crucial in the development of their life history strategies: the dispersion of food resources, their irregular and unpredictable fluctuations, and the constraint for adult seabirds to transport and conserve food from the feeding areas to the breeding areas (Ricklefs 1983). The parent pelagic seabird brings back food for its offspring by carrying meals in its stomach (Croxall 1984, Wilson et al. 1989). Due to remoteness of the feeding site and the method of food transport, the frequency of chick feeding and meal size are limited (Ricklefs 1983, Costa 1991). These constraints are particularly critical at hatching time when the chick needs to be fed quickly, as its own body reserve is limited to the yolk sac (Reid \& Bailey 1966).

Among pelagic birds, King penguins breeding at sub-Antarctic islands face quite extreme feeding conditions. They rely essentially on myctophid fish (Cherel \& Ridoux 1992, Olsson \& North 1997, Moore et al. 1998). These fish constitute a major biomass of the Southern Ocean and at the time of hatching of King penguins are mostly available at the Antarctic Polar Front at the limit between the Subantarctic and Antarctic waters (Bost et al. 1997, Rodhouse et al. 1998, Moore et al. 1999, Koudil et al. 2000). Concerning the Crozet Archipelago, not only is this front usually 400 to $500 \mathrm{~km}$ south, but it can move even farther south with interannual changes related to the circumpolar wave, a phenomenon thought to be connected to the ENSO (El Niño southern oscillation) phenomenon (White \& Peterson 1996, Peterson \& White 1998). Furthermore, the Antarctic Polar Front moves south at the end of the summer (Moore et al. 1999). The unpredictable and patchy availability of marine resource location results in highly variable durations of penguin foraging trips at sea (Le Maho et al. 1993, Gauthier-Clerc et al. 2001). This variation determines which mate is with the egg when hatching occurs. Since the survival of the newly hatched chick depends on the regurgitation of food by the parent present at that time, a key question is therefore as to how a breeder can cope with a delay of its mate's return. The incubating male King penguin preserves food in his stomach for several weeks, which enables him to feed the chick if hatching occurs (Gauthier-Clerc et al. 2000). Moreover, as this species pre- sents a non-synchronised breeding cycle, laying extends over as much as 4 mo, i.e. from November to February (Stonehouse 1960, Barrat 1976); therefore, there is a different resource availability for late breeders during the incubation period and at the time of hatching.

This study aims to determine the food-provisioning strategy of King penguins at hatching time in this unpredictable environment. We investigated the foraging trip duration relative to the laying date and the Polar Front position, as well as adult body mass regulation and the meal size for chicks according to the hatching date. We compare in both early and late breeders the energy content and the chemical and diet composition of the meals stored in their stomachs.

\section{MATERIALS AND METHODS}

Study site and animal model. The study was carried in a colony of 25000 pairs at Possession Island $\left(46^{\circ} 25^{\prime} \mathrm{S}, 51^{\circ} 45^{\prime} \mathrm{E}\right)$, Crozet Archipelago. King penguins are pelagic, diving birds feeding several $100 \mathrm{~km}$ from their breeding colony at Crozet (Jouventin et al. 1994, Bost et al. 1997). They catch mainly myctophid fishes and squids by diving between 50 and $400 \mathrm{~m}$ (Kooyman et al. 1992, Pütz \& Bost 1994, Bost et al. 1997, Charrassin et al. 1998). The breeding cycle of the King penguin lasts for more than 1 yr. The constraints of breeding and moult necessitate an alternation of foraging at sea, during which time the birds restore their body reserves, with periods of fasting on shore. Courting lasts for $10 \mathrm{~d}$ on average (Gauthier-Clerc et al. 2001). After mating in the colony, the female lays 1 egg, incubates it for a few hours and then goes to sea after exchanging the egg with the male. There is 1 laying per year. Birds are not synchronised in their laying date and 2 peaks of laying are observed: a first peak of early breeders which failed their previous breeding season, and a second peak of late breeders which succeeded in fledging a chick during the previous breeding season (Barrat 1976; see Fig. 1). After the female lays her egg, both mates relieve each other during incubation that lasts for $54 \mathrm{~d}$ on average (Handrich 1989). The female undertakes the first incubation shift (Shift 1) that lasts for anything between a few hours up to $2 \mathrm{~d}$ after laying, and the third shift (Shift 3) (Stonehouse 1960, Barrat 1976). The male assumes Shifts 2 and 4 (Fig. 1). The incubating adult fasts for several weeks and never leaves the egg during this period. At the same time, the non-incubating partner feeds on myctophid fishes and accumulates body reserves of mainly fat (Cherel et al. 1994).

Bird identification and observation. In 1993 to 1994, we determined the incubation routine and body mass 
variations using an automatic identification and weighing system. Breeding King penguins were automatically weighed and identified when they crossed a weighbridge at the single opening of an enclosure (see Gendner et al. 1992, Le Maho et al. 1993, GauthierClerc et al. 2001 for a complete description). Individual identification was based on the permanent implantation of a miniature transponder tag (TIRIS) weighing $0.8 \mathrm{~g}$ under the skin of the bird's back. The birds were identified and weighed each time they passed the weighbridge at the beginning and end of each foraging trip. The birds were also banded with metal flipper rings to permit visual observations with binoculars. Courtship or egg exchange was used to identify the breeding partner if one of the birds was marked. The sex of the birds was determined according to the stage of the incubation cycle and confirmed by listening to display songs (Stonehouse 1960, Barrat 1976, Jouventin 1982). Individual weights (i.e. weighbridge crossing events) were analysed with custom-made software (J. P. Gendner, CEPE-CNRS). This interactive program allows the selection of the largest steady-state section of the weighing signal and accordingly to calculate the body weight. We calibrated the weighbridge regularly (every $2 \mathrm{mo}$ ) with a $5 \mathrm{~kg}$ standard mass. Accuracy of measurements was between \pm 30 and $\pm 100 \mathrm{~g}$, that is, $1 \%$ of King penguin body mass, depending on the waddling gait of the birds and wind velocity. The time of return from the hatching date was determined for 46 breeding females. We determined the incubation routine and body mass variations of 15 pairs for which all body mass data were available. All these birds had already been fitted with transponders when breeding during the 3 previous summers.

From December 1995 to April 1996, we determined the meal size (see later) for chicks according to the hatching date. After laying, birds were individually marked with plastic flipper bands engraved with large numbers. We distinguished 2 groups: early breeders (laying dates from 19 to 31 December 1995) and late breeders (laying dates from 22 January to 15 February 1996). Both partners of 44 pairs and males only of 79

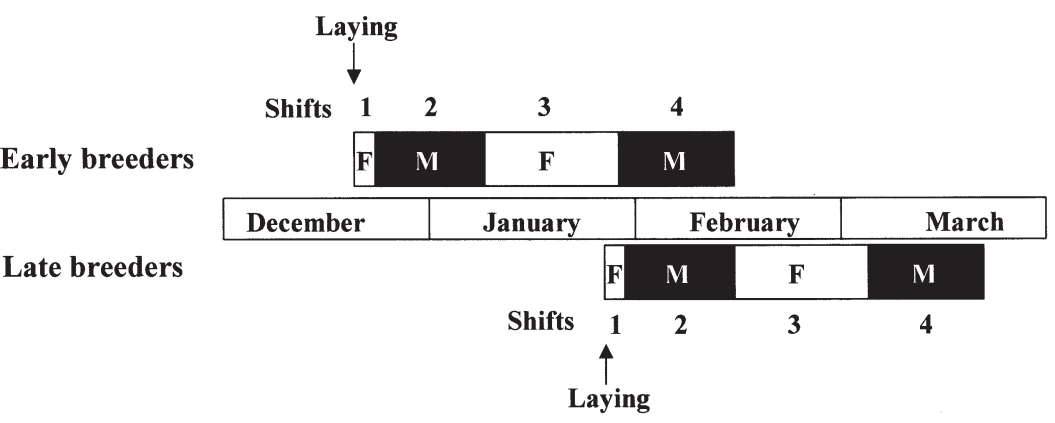

Fig. 1. Schematic representation of incubation shifts of early breeders and late breeders in relation to the date ( $\mathrm{F}=$ female; $\mathrm{M}=$ male) pairs were banded in the early breeders, and males of 76 pairs were banded in the late breeders. To ensure sufficient data, a larger number of birds than was probably necessary were marked to take into account birds failing in their reproduction and birds missed when returning to the colony or departing to sea. Breeding areas and beaches were checked daily with a telescope and binoculars to determine incubation shifts and to catch birds at their departure to sea or arrival in the colony. Birds not caught for stomach content sampling were used to determine the mean duration of foraging trips at sea and incubation shifts.

Oceanic features. The Crozet Archipelago lies between the Sub-Antarctic Front (localised at $43^{\circ} \mathrm{S}$ ) and the Polar Front (localised at about $50^{\circ} \mathrm{S}$ in April), which are major fronts of the Southern Ocean. The Polar Front is defined by the northernmost extent of the subsurface $2^{\circ} \mathrm{C}$ temperature minimum, which corresponds approximately to a sea surface temperature (SST) of 4 to $5^{\circ} \mathrm{C}$ (Parks et al. 1998). SST was obtained from the weekly National Centers for Environmental Prediction SST analysis of the National Oceanic and Atmospheric Administration (NOAA, Asheville, NC, $\mathrm{USA}_{i} \quad$ http://ferret.wrc.noaa.gov/fbin/climate_server) with a latitude/longitude resolution of $1^{\circ}$. We used weekly SST data from 2 November 1993 to 15 March 1994, and 31 October 1995 to 19 March 1996 on $51.5^{\circ}$ longitude east and from $46.5^{\circ}$ to $53.5^{\circ}$ latitude south.

Meal sampling. Only 1 single measurement of stomach content was made on a same individual or on partners of a pair in order to avoid potential bias in digestive physiology or in behaviour of the individual. Among early breeders we distinguished 3 groups of females and 3 groups of males. Females: those departing at the end of Shift 1, arriving at the beginning of Shift 3 or departing at the end of Shift 3. Males: departing at the end of Shift 2, arriving for assuming Shift 4 or departing at the end of Shift 4. Among late breeders we caught 2 groups of males: those arriving for Shift 4 or departing at the end of Shift 4 . The number of individuals sampled was limited to 5 or 10 in some groups so as to minimise disturbance to the birds. Flipper bands were removed after stomach sampling or at the end of the study.

Before stomach flushing, a plastic feeding tube was gently introduced into the stomach of some individuals and a 5 to $10 \mathrm{ml}$ sample of the stomach content was drawn and frozen. These samples were used to measure gastric $\mathrm{pH}$. Unlike albatrosses and petrels, penguins do not spontaneously regurgitate food when handled by humans. The stomach content was obtained by a method of stomach flushing adapted from Wilson (1984). Two succes- 
sive flushings were conducted to make sure that we obtained all the stomach contents. The birds were refed with their food after stomach sampling so as not to disrupt chick feeding. The birds were weighed before and after stomach flushing. Stomach contents were drained and weighed by the same person each time.

Chemical composition analysis of the meal. Half of the sample was used for chemical analysis and the other half for determination of diet composition. First, samples for chemical analysis were weighed and dried by lyophilisation. Water content was determined by the difference between the wet mass and the lyophilised mass of the sample. Stones, i.e. gastroliths, were removed before weighing the dry mass. Chemical composition (total lipid, protein, ash) was determined from aliquots. Samples were crushed and homogenised. A $1 \mathrm{~g}$ aliquot was used for the measurement of total lipids, which were determined by a method adapted from Folch et al. (1957). Lipids were extracted with a mixture of chloroform:methanol (2:1). After centrifuging, the supernatant with methanol and water was discarded. The lower phase containing chloroform and lipids was evaporated and the remaining lipids were weighed. A $100 \mathrm{mg}$ aliquot was measured by micro-Kjeldahl analysis to determine the nitrogen content. A $3 \mathrm{~g}$ aliquot was heated at $500^{\circ} \mathrm{C}$ for $48 \mathrm{~h}$ and then weighed for the mineral ash content.

Glycogen content was assumed to be negligible and consequently not measured (Newsholme \& Leech 1988). The energy content of the stomach content was calculated assuming that the energy density of lipid is $39.3 \mathrm{~kJ} \mathrm{~g}^{-1}$ and that of protein to uric acid is $17.8 \mathrm{~kJ} \mathrm{~g}^{-1}$ (Schmidt-Nielsen 1979). Gastric $\mathrm{pH}$ was measured from samples drawn before stomach flushing and after centrifuging the sample.

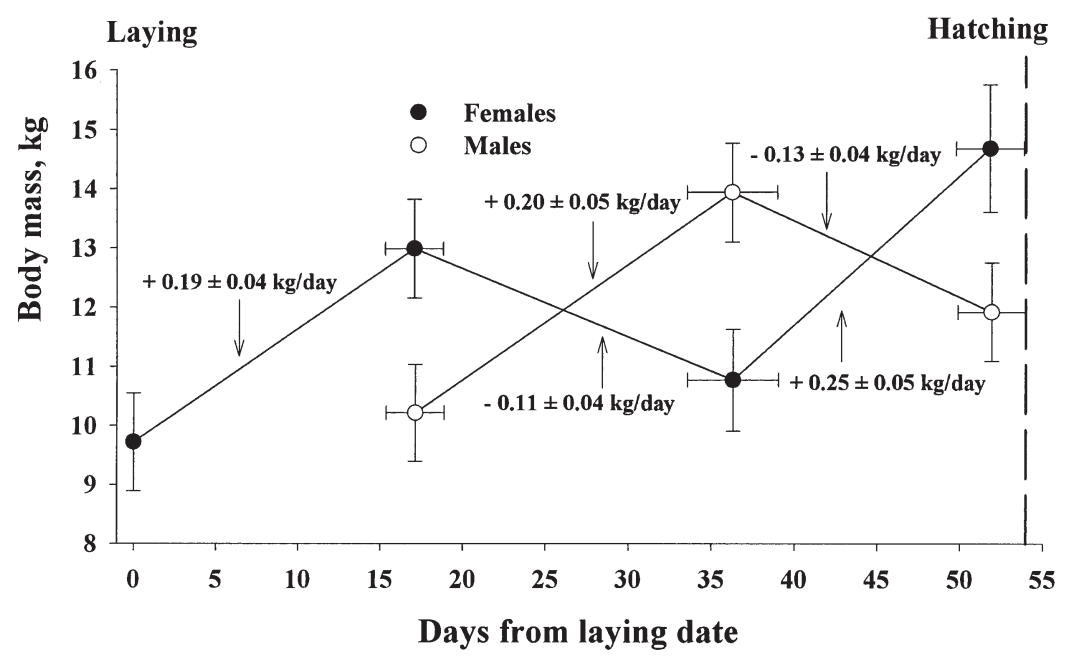

Fig. 2. Body mass variations in relation to laying date in 15 pairs of King penguins breeding in summer 1993 to 1994, taken from automatic identification and weighing data. Means \pm SD are shown
Diet composition. Identification of fish prey was based on the morphology of otoliths using identification keys (Gon \& Heemstra 1990) and a reference collection (C. Bost, CEPE-CNRS). Mandibles were used to confirm identification. The frequency and occurrence of fish species were calculated from their otoliths. Otoliths that were too eroded to be identified were not included in the analysis. Squid frequency was calculated from the number of beaks with flesh attached, and occurrence with the presence of fresh organs or beaks with flesh attached. The Shannon diversity index $(H)$ was calculated to determine the diversity of prey species: $H=-\sum q i / Q \log _{2} q i / Q$, i.e. $H=3.322$ $\left[\log Q-1 / Q \sum q i \log _{10} q i\right]$, with $Q=$ total number of identified otoliths and $q i=$ relative frequencies of fish prey (Begon et al. 1986).

Data analysis. Nonparametric statistics were performed when the assumptions for parametric tests were not met (Siegel \& Castellan 1988). Results were considered to be significant at the $5 \%$ level. Means are reported $\pm \mathrm{SE}$.

\section{RESULTS}

\section{Food provisioning at hatching}

Out of 32 females laying in December 1993, 21 came back from their second foraging trip at sea before the hatching date whereas 11 came back afterwards (on average for all birds: $1.7 \pm 0.7 \mathrm{~d}$ before hatching). Of 14 females laying in January 1994, only 6 arrived before the hatching date while 8 came after (on average for all birds: $2.7 \pm 1.7 \mathrm{~d}$ after hatching). The incubation routine and body mass variations are illustrated for 15 pairs in Fig. 2. In 1995 to 1996, female early and late breeders returned from their first foraging trip on average $38 \pm 1 \mathrm{~d}(\mathrm{n}=92)$ and $35 \pm 1 \mathrm{~d}(\mathrm{n}=68)$ before hatching, without food in the stomach $(41 \pm 10 \mathrm{~g}[\mathrm{n}=10]$ and $25 \pm 1 \mathrm{~g}[\mathrm{n}=4]$ respectively). The first foraging trip at sea of both female and of male late breeders was longer than for early breeders $(+3 \mathrm{~d}, U=445, \mathrm{p}<0.001$ and $+29 \mathrm{~d}, U=24, \mathrm{p}<0.001$, respectively; see Fig. 3). In particular, the duration of the foraging trips at sea increased greatly between male early and late breeders. Male early and late breeders returned from first foraging trips $17 \pm 0.7 \mathrm{~d}$ before hatching $(\mathrm{n}=77)$ and $11 \pm 3 \mathrm{~d}$ after hatching $(\mathrm{n}=52)$, respectively (12 birds not included because they returned only during the next breeding season). The end of the summer 1995 to 1996 was marked by a local sea-warming, 


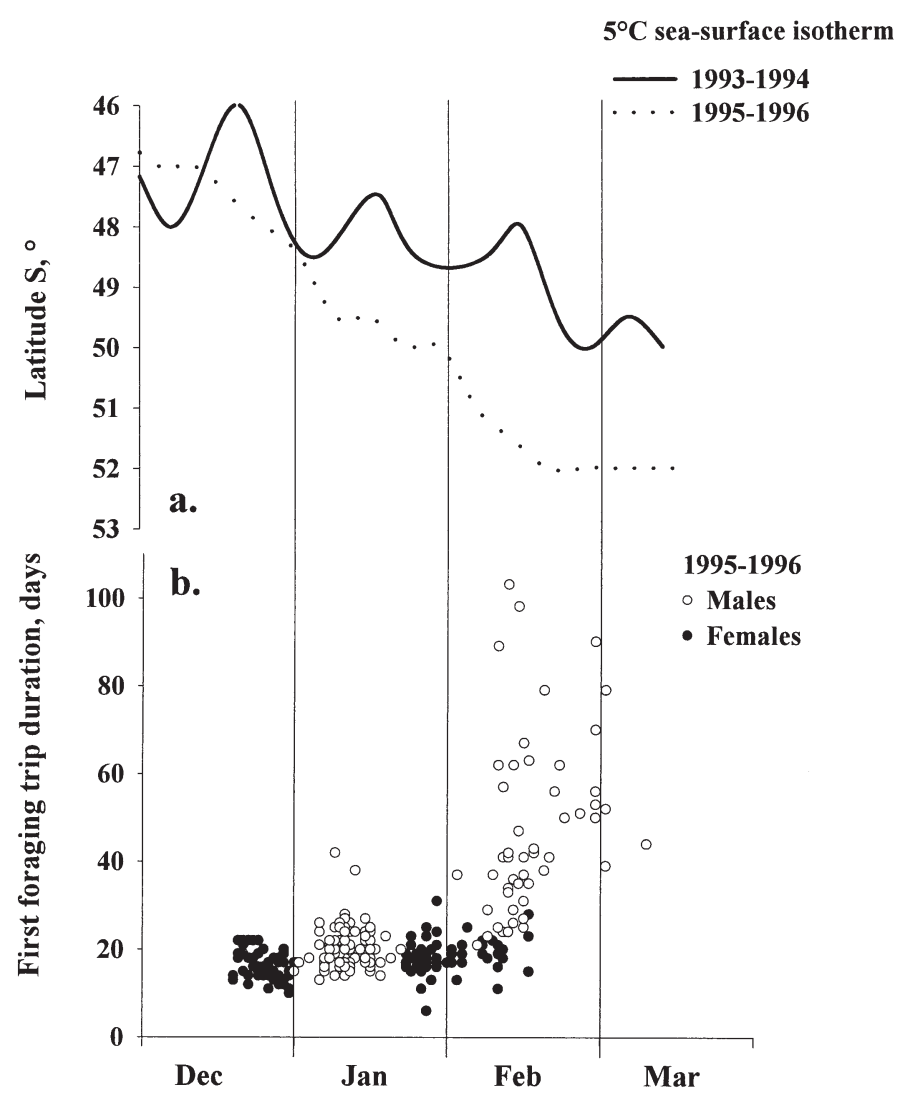

Fig. 3. (a) Position of the $5^{\circ} \mathrm{C}$ sea surface temperature isotherm in the 1993 to 1994 and 1995 to 1996 summers at longitude $51^{\circ} 5^{\prime} \mathrm{E}$. (b) Duration of the first foraging trips at sea of females and males according to date of departure to sea in summer 1995 to 1996

the position of the Antarctic Polar Front being $200 \mathrm{~km}$ south of its mean position in the Crozet sector and its position in 1993 to 1994 (Fig. 3). Ninety percent of early male breeders $(n=20)$ returning from the first foraging trip had food in their stomach. In addition to early breeders (Group A), late male breeders were segregated into 2 distinct groups: males that foraged at sea for less than $50 \mathrm{~d}$ (i.e. that returned to the colony less than $13 \mathrm{~d}$ after the hatching date, Group $\mathrm{B}, \mathrm{n}=22$ ), and males that foraged at sea for more than $50 \mathrm{~d}$ (i.e. those that returned to the colony more than $13 \mathrm{~d}$ after the hatching date; Group C, n = 18; Fig. 4). In Group B, 21 individuals $(95 \%)$ had food in their stomach while only 4 individuals (20\%) had food in Group C. Late breeders of Group B had more food than early breeders (571 $\pm 66 \mathrm{~g}$ vs $191 \pm 28 \mathrm{~g} ; U=64, \mathrm{p}<0.001)$. Conversely, late breeders of Group $\mathrm{C}$ had less food than late breeders of Group B $(65 \pm 16 \mathrm{~g}, \mathrm{U}=15, \mathrm{p}<0.001)$ and less than early breeders of Group A $(U=58.5, \mathrm{p}<$ 0.01). Male late breeders had a larger body mass than male early breeders, $14.28 \pm 0.20 \mathrm{~kg}(\mathrm{n}=40)$ vs $13.43 \pm$ $0.14 \mathrm{~kg}(\mathrm{n}=20)$, respectively $(U=223, \mathrm{p}<0.01)$. The estimated daily gain of body mass was greater in early breeders than in late, $+212 \mathrm{vs}+117 \mathrm{~g} \mathrm{~d}^{-1}$, whereas estimated daily food storage for chicks was quite similar, $+11 \mathrm{vs}+13 \mathrm{~g} \mathrm{~d}^{-1}$.

\section{Chemical composition of stomach content}

Proportionally, there was more water in the stomach content of late breeders $(U=67, \mathrm{p}<0.001$; see Table 1$)$. Lipid and protein expressed as percentage dry mass were not significantly different $(U=157$ and 120.5, respectively). Ash content was significantly lower in late breeders $(U=35.5, \mathrm{p}<0.001)$.

\section{Energy content of stomach content}

The energy content of the meal was significantly higher in late breeders than in early breeders (3296 kJ vs $1333 \mathrm{~kJ}$, respectively; $U=72$, p $<0.01$; Table 2). There was no difference per gram of wet mass $(U=$ 121.5, not significant), but it differed per gram of dry mass $\left(19 \mathrm{~kJ} \mathrm{~g}^{-1}\right.$ in early breeders vs $21 \mathrm{~kJ} \mathrm{~g}^{-1}$ in late breeders; $U=90, \mathrm{p}<0.01$ ).

\section{Diet composition}

For both early and late breeders, myctophid fishes were present in all the meals and constituted more

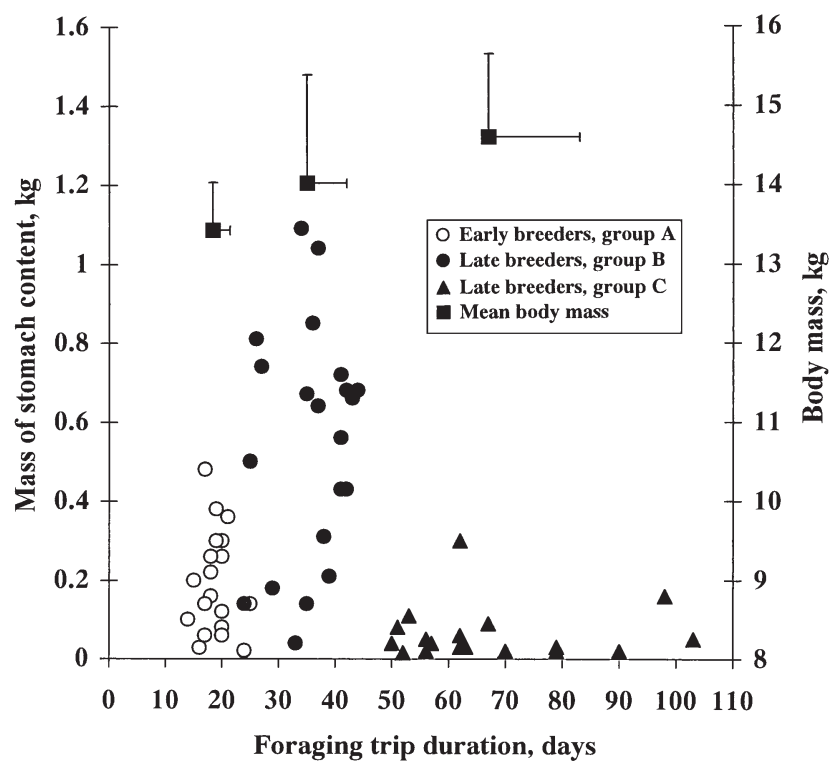

Fig. 4. Mass of stomach content (with food or without food) and mean body mass \pm SD of male King penguins according to duration of foraging trip. Three groups are distinguished: early breeders, Group A; late breeders, Group B (foraging trip shorter than $50 \mathrm{~d}$ ); and late breeders, Group C (foraging trip longer than $50 \mathrm{~d}$ ) 
Table 1. Chemical composition of male stomach contents at arrival from the first foraging trip at sea and at departure to sea after the incubation fast (Shift 4)

\begin{tabular}{|c|c|c|c|c|c|c|c|}
\hline & \multicolumn{4}{|c|}{ Percentage of wet mass } & \multicolumn{3}{|c|}{ Percentage of dry mass } \\
\hline & Water & Lipid & Protein & Ash & Lipid & Protein & Ash \\
\hline \multicolumn{8}{|l|}{ Early breeders } \\
\hline Arriving from sea $(n=17)$ & $67.8 \pm 1.0$ & $7.6 \pm 0.5$ & $18.0 \pm 0.8$ & $5.0 \pm 0.3$ & $23.4 \pm 1.2$ & $55.7 \pm 1.6$ & $15.5 \pm 1.0$ \\
\hline Departing to sea $(n=13)$ & $66.1 \pm 0.7$ & $5.4 \pm 0.5$ & $23.1 \pm 0.6$ & $3.2 \pm 0.2$ & $15.9 \pm 1.2$ & $68.2 \pm 0.9$ & $9.5 \pm 0.6$ \\
\hline \multicolumn{8}{|l|}{ Late breeders } \\
\hline Arriving from sea $(n=22)$ & $72.6 \pm 0.7$ & $6.9 \pm 0.4$ & $16.2 \pm 0.4$ & $2.8 \pm 0.2$ & $25.1 \pm 1.2$ & $59.5 \pm 1.2$ & $10.0 \pm 0.6$ \\
\hline
\end{tabular}

Table 2. Energy content of stomach content of males at arrival from their first foraging trip at sea and at departure to sea after the incubation fast (Shift 4)

\begin{tabular}{|c|c|c|c|c|}
\hline & \multirow{2}{*}{$\mathrm{n}$} & \multicolumn{3}{|c|}{ Energy content } \\
\hline & & $\begin{array}{l}\text { Wet mass } \\
\left(\mathrm{kJ} \mathrm{g}^{-1}\right)\end{array}$ & $\begin{array}{c}\text { Dry mass } \\
\left(\mathrm{kJ} \mathrm{g}^{-1}\right)\end{array}$ & $\begin{array}{l}\text { Absolute value } \\
\qquad(\mathrm{kJ})\end{array}$ \\
\hline \multicolumn{5}{|l|}{ Early breeders } \\
\hline Arriving from sea & 17 & $6.2 \pm 0.2$ & $19.2 \pm 0.4$ & $1333.5 \pm 171.1$ \\
\hline Departing to sea & 13 & $6.3 \pm 0.2$ & $18.5 \pm 0.4$ & $2086.9 \pm 231.6$ \\
\hline Late breeders & & & & \\
\hline Arriving from sea & 22 & $5.6 \pm 0.2$ & $20.6 \pm 0.3$ & $3295.6 \pm 391.8$ \\
\hline
\end{tabular}

the squid parts were intact. Certain meals showed a green or yellow coloration that was probably due to biliary pigments from intestinal reflux. Twenty-one out of 33 male early breeders conserved food during the second incubation shift $(16 \pm 1 \mathrm{~d})$. The amount of food stored was not significantly different from males returning from the first foraging trip with food $(0.248 \pm 0.033 \mathrm{~kg}$, $\mathrm{n}=21$ vs $0.210 \pm 0.028 \mathrm{~kg}, \mathrm{n}=18$; MannWhitney test: $U=115.5, \mathrm{p}>0.05)$. Out of the 12 empty males at departure, 7 birds either had arrived at the colony without food or digested it during the incubation than $90 \%$ of the prey species (see Table 3). The Paralepididae family was present in only $10 \%$ of the meals and constituted less than $1 \%$ of the prey species. Nine and 13 fish species were identified in early and late breeders, respectively. In early breeders, $92 \%$ of the prey consisted of 4 species of myctophids: Krefftichthys anderssoni (53\%), Electrona carlsbergi $(17 \%)$, Protomyctophum bolini $(13 \%)$ and P. tenisoni (9\%). In late breeders, $85 \%$ of prey consisted of 4 species of myctophid fishes: P. tenisoni (45\%), P. bolini $(17 \%)$ E. carlsbergi $(16 \%)$ and $K$. anderssoni $(7 \%)$. Although present in $80 \%$ of the meals of early breeders and in $95 \%$ of those of late breeders, squids represented only 5 and $9 \%$ of the prey species, respectively. The diet composition was significantly different between early and late breeders $\left(\chi^{2}{ }_{5}=62.21, \mathrm{p}<\right.$ 0.001). The Shannon diversity index was higher for late breeders than for early breeders $(H=2.4$ vs $H=2.1$, respectively).

\section{Meal conservation during the long-term storage in the stomach}

In 1995 to 1996, the state of preservation of the prey in the bird's stomach after 2 to $3 \mathrm{wk}$ of storage during the incubation was analysed in male early breeders. The fish remains appeared as a mash and shift, and 5 had given all the meal to the newly hatched chick.

The stomach contents of males returning to the colony with food had a higher $\mathrm{pH}$ than those of males returning with an empty stomach (pH 4.1 vs 2.9, respectively; $t$-test: $t_{24}=11.0, \mathrm{p}<0.001$; Table 4 ). Similarly, after the incubation fast, males still with food had a higher gastric $\mathrm{pH}$ than males without food (pH 3.2 vs 2.1 , respectively; $t$-test: $\left.t_{24}=14.5, \mathrm{p}<0.001\right)$. The gastric $\mathrm{pH}$ of the food contents was significantly lower after than before the storage $(\mathrm{pH} 3.2$ vs 4.1 , respectively; $t$-test: $\left.t_{38}=15.6, \mathrm{p}<0.001\right)$. The percentage of water in the food content was not different between arrival and departure $(U=80, \mathrm{~ns}$; Table 1$)$. Lipid and ash in wet mass and in dry mass were significantly lower at departure to sea $(U=44.5, \mathrm{p}<0.01$ and $U=21$, $\mathrm{p}<0.01$ in wet mass and $U=25, \mathrm{p}<0.01$ and $U=14.5$, $\mathrm{p}<0.01$ in dry mass, respectively). Conversely, the proportion of protein was higher at departure to sea $(U=19, \mathrm{p}<0.01$ in wet mass and $U=13.5, \mathrm{p}<0.01$ in dry mass).

The energy content per gram of wet or dry stored meal was not significantly different between the beginning and the end of the incubation shift (MannWhitney tests: $U=102, \mathrm{p}>0.05$ and $U=71, \mathrm{p}>0.05$, respectively; see Table 2$)$. The total energy content of the meal was higher after storage $(U=50, \mathrm{p}<0.05)$ because the mass of the samples of birds departing to 
Table 3. Frequency of occurrence and frequency by number of prey species in stomach contents of early and late male breeders when returning from their first foraging trip at sea

\begin{tabular}{|c|c|c|c|c|}
\hline \multirow[t]{2}{*}{ Prey } & \multicolumn{2}{|c|}{$\begin{array}{l}\text { Frequency of } \\
\text { occurrence (\%) }\end{array}$} & \multicolumn{2}{|c|}{$\begin{array}{c}\text { Frequency by } \\
\text { number }(\%)\end{array}$} \\
\hline & $\begin{array}{c}\text { Early } \\
(\mathrm{n}=18)\end{array}$ & $\begin{array}{c}\text { Late } \\
(\mathrm{n}=26)\end{array}$ & $\begin{array}{c}\text { Early } \\
(\mathrm{n}=509)\end{array}$ & $\begin{array}{c}\text { Late } \\
(\mathrm{n}=894)\end{array}$ \\
\hline \multicolumn{5}{|l|}{ Fishes } \\
\hline Paralepididae & 10 & 10 & 0.6 & 0.3 \\
\hline Magnisudis prionosa & 0 & 0 & 0.0 & 0.2 \\
\hline Notolepis coatsi & 5 & 0 & 0.4 & 0.0 \\
\hline Notolepis rissoi & 5 & 0 & 0.2 & 0.0 \\
\hline Paralepis coregonoides & 0 & 5 & 0.0 & 0.1 \\
\hline Myctophidae & 100 & 100 & 94.5 & 90.5 \\
\hline Electrona carlsbergi & 65 & 75 & 16.8 & 16.5 \\
\hline Electrona subaspera & 0 & 5 & 0.0 & 0.2 \\
\hline Electrona antarctica & 0 & 10 & 0.2 & 0.4 \\
\hline Gymnoscopelus nicholsi & 5 & 5 & 0.8 & 0.1 \\
\hline Gymnoscopelus fraseri & 0 & 15 & 0.0 & 1.1 \\
\hline Gymnoscopelus piabilis & 0 & 5 & 0.0 & 0.1 \\
\hline Krefftichthys anderssoni & 85 & 60 & 52.7 & 6.6 \\
\hline Protomyctophum andriashevi & 0 & 15 & 0.0 & 1.1 \\
\hline Protomyctophum bolini & 65 & 75 & 13.2 & 17.1 \\
\hline Protomyctophum choriodon & 5 & 20 & 0.2 & 2.1 \\
\hline Protomyctophum gemmatum & 10 & 15 & 1.8 & 0.7 \\
\hline Protomyctophum tenisoni & 55 & 90 & 8.8 & 44.5 \\
\hline Squids & 80 & 95 & 4.9 & 9.2 \\
\hline Unidentified squids & 80 & 95 & 4.9 & 9.2 \\
\hline
\end{tabular}

When the probability of hatching during the incubation shift was very low (Shifts 1, 2 and 3), the adults fasted with an empty stomach. Indeed, the females returning from the first foraging trip carried energy only as lipid, which is a high-energy and lightweight food store. In contrast, the large majority of males anticipated possible hatching by having a longterm food storage in their stomach during incubation of Shift 4 (GauthierClerc et al. 2000). Energy was carried to the colony by the males as lipid stores to cover their costs during incubation and as a small amount of undigested food for their future chick. The King penguin is thus capable of digesting at a very high rate when foraging for itself and just afterwards to completely stop assimilating energy, after which he stores food in his stomach. This assumes a high flexibility of the digestive processes. In the case of short foraging trips, the female may return up to $9 \mathrm{~d}$ before hatching (observed during both 1994 and 1996), which suggests that, like the male, the

Table 4. Gastric pH of males arriving from sea and departing to sea after the incubation fast

\begin{tabular}{|lcccc|}
\hline & \multicolumn{2}{|c|}{$\begin{array}{c}\text { Arriving from sea } \\
\text { With } \\
\text { food }\end{array}$} & $\begin{array}{c}\text { Without } \\
\text { food }\end{array}$ & $\begin{array}{c}\text { Departing to sea } \\
\text { With food } \\
\text { (after long- } \\
\text { term storage })\end{array}$ \\
\hline $\begin{array}{l}\text { Gastric } \\
\text { pH }\end{array}$ & $\begin{array}{c}4.1 \pm 0.1 \\
(\mathrm{n}=21)\end{array}$ & $\begin{array}{c}2.9 \pm 0.1 \\
(\mathrm{n}=5)\end{array}$ & $\begin{array}{c}3.2 \pm 0.1 \\
(\mathrm{n}=19)\end{array}$ & $\begin{array}{c}2.1 \pm 0.1 \\
(\mathrm{n}=7)\end{array}$ \\
\hline
\end{tabular}

sea used for chemical composition was on average higher than those of birds arriving from sea (330 \pm 33 vs $219 \pm 28 \mathrm{~g})$.

\section{DISCUSSION}

\section{Food-provisioning at hatching}

Our data show that most female early breeders come back from their second foraging trip at sea a short time before hatching. However, the date of return is highly variable. Even for early breeders, as many as $1 / 3$ of the females arrived after the hatching date. Thus, despite coming back several weeks before hatching, early male breeders were present $1 / 3$ of the time at hatching. female is also able to store food in her stomach for the chick during a long period of incubation.

This strategy of food provisioning for hatching time is different from those previously described in the other pelagic seabirds. In many species such as albatrosses, adults shorten the duration of their foraging trip at sea at the end of the incubation period, which increases the likelihood that they can feed the chick soon after hatching (Croxall 1984). In some other species of seabirds, the adults adjust the duration of their foraging trip at sea to the hatching date (in Adélie penguins Pygoscelis adeliae, Davis \& Miller 1990, Davis et al. 1995; in Grey-faced petrels Pterodroma macroptera, Johnstone \& Davis 1990). In Adélie penguins, the incubating adult has no food in the stomach and the foraging adult curtails the duration of its trip if hatching is imminent (Davis \& Miller 1990, Davis et al. 1995). However, $6 \%$ of chicks die of starvation due to a prolonged delay in an adult's return (Davis \& McCaffrey 1986). In the Emperor penguin Aptenodytes forsteri, the closest relative of the King penguin, females come back on average $10 \mathrm{~d}$ after hatching, while incubating males have fasted for up to 4 mo (Prévost 1961). In this species, the strategy is different because a male fasting for 4 mo can feed its newly hatched chick with an energy-rich oesophageal secretion (Prévost \& Vilter 1963). 


\section{Meal conservation during long-term storage in the stomach}

After being stored several weeks in the stomach, the meal showed a visual aspect, a mass and an energetic value remarkably similar to those upon arrival at the colony. This implies a modification of the digestive process, a conservation against bacterial fermentation and a permanent closure of the pyloric valve. Observations of intestinal reflux with biliary pigments and an increase in the number of birds without food at the end of the incubation shift suggests that a few birds opened the pyloric valve and may have digested their meal during incubation. Delayed gastric emptying has also been shown in breeding African penguins Spheniscus demersus. The adult can still feed its chick $24 \mathrm{~h}$ after returning from the sea. This duration is longer than the time for gastric emptying in non-breeding adults (Wilson et al. 1989). Although not studied, the female Emperor penguin may also stop the gastric emptying since the female brings back a $3 \mathrm{~kg}$ meal for the newly hatched chick and can feed it for 2 to 4 wk (Isenmann 1971, Kirkwood \& Robertson 1997). According to our data, the cessation of digestive processes is not complete as the meal shows some modifications in biochemical composition during storage, especially a decrease in total lipid content. Conversely to the oil storage and protein digestion in albatrosses and petrels (Clarke \& Prince 1976, Jackson $\&$ Place 1989), proteins are stored here. The decrease in lipid composition may be due either to a loss of oils through the pylorus or to a complete degradation to water and carbon dioxide by bacteria. Roby et al. (1989) showed that the mean retention time for the lipid phase was longer in penguins than in petrels. The pyloric valve shows a dorsal position relative to the stomach of penguins and a ventral position in procellariiforms (Roby et al. 1989). This means that in the case of a separation of the aqueous phase from the lipid phase, the latter may leave the penguin's stomach, contrary to that observed in procellariiforms.

The lower acidity observed in the stomach with food and the slight decrease of $\mathrm{pH}$ (only 4 to 3 ) during the incubation shift may result from a decrease of the acid secretions of the stomach. During chick rearing in the Magellanic penguin Spheniscus magellanicus, Peters (1997) found a high flexibility of the gastric $\mathrm{pH}$, increasing to $\mathrm{pH}=6$ during the $12 \mathrm{~h}$ before the adult returned to the breeding colony. This result was interpreted as a process to slow down the digestion until chick feeding, since gastric enzymes are adapted to acid conditions (Peters 1997). The value of gastric $\mathrm{pH}$ measured in our study probably still allowed enzymes to work (Peters 1997). The biochemical mechanism involved in the stomach of the King penguin to protect food and prevent bacterial fermentation still has to be elucidated.

\section{Comparison of meal and body mass regulation in early and late breeders}

The longer duration of foraging trips of late breeders means that there is a greater likelihood that males have to feed the chick at hatching. Following a local sea-warming in 1996, the foraging trip of male late breeders greatly increased, being on average $29 \mathrm{~d}$ longer than for early breeders. In comparison, Weimerskirch et al. (1992) measured a difference of $+7 \mathrm{~d}$ in foraging trip of male late breeders compared to early ones in 1975 to 1976 . The position of the $5^{\circ} \mathrm{C} \mathrm{SST}$ isotherm in February 1976 was similar to February 1994 , i.e. at longitude $49.5^{\circ} \mathrm{S}$, whereas it was at longitude $52.0^{\circ} \mathrm{S}$ in February 1996.

Males brought back to the colony an amount of food adjusted to the delay to the hatching date. The amount of stored food, several $100 \mathrm{~g}$, is far from the maximum capacity of the stomach (up to $4.5 \mathrm{~kg}$, Pütz \& Bost 1994), but considering a basal metabolism of $5.2 \mathrm{~W}$ $\mathrm{kg}^{-1}$ in a newly hatched chick (Barré 1978), the meal is enough to keep the newly hatched chick alive for a delay of up to $10 \mathrm{~d}$ in the female of early breeders. This is in accordance with the finding that the 5 males with empty stomachs at departure to sea had been watched feeding their chicks for $9 \pm 1 \mathrm{~d}$. However, the males returning to the colony $13 \mathrm{~d}$ or more after hatching carried no food for the chick. Even if the female had not abandoned the egg before hatching, since she had no food in her stomach, the chick would not have survived. These males had mostly no food in their stomach but had allocated larger fuel reserves for themselves than males returning earlier. This may imply that a decision to abandon breeding was made during the foraging trip at sea and suggests the existence of some kind of internal clock that allows the adult to adjust its parental effort (Hector et al. 1986, Davis \& Miller 1990). It is not unusual that these birds returned to the colony after abandonment, because King penguins frequent their breeding area all year round even when they have been unsuccessful breeders (Descamps et al. 2002). In Adélie penguins, the adjustment of the trip duration to the hatching date has been linked to an increase in progesterone level (Davis et al. 1995). The blood prolactin level does not change between incubation and chick brooding in King penguins (Cherel et al. 1994), which may suggest that meal size adjustment and food storage is also controlled in part by progesterone.

The fact that late breeders did not reduce their foraging trip duration, but rather built up larger fuel reserves than early breeders, may be interpreted as reflecting the trade-off in long-lived birds favouring adult survival to that of offspring survival (Stearns 1992). It also reflects the need for a greater safety margin in response 
to a lower availability of fish prey. Whereas late breeders of Group B showed a larger body mass and a larger meal, the energetic output per day foraging at sea was much lower than for early breeders. This agrees with the assumption that during the incubation period late breeders had greater difficulties foraging at sea compared to early breeders several weeks before. The diet composition supports this view. Our data are in agreement with previous studies showing that myctophid fishes are the main prey of King penguins at Crozet Archipelago in early summer (Cherel \& Ridoux 1992, Cherel et al. 1996, Bost et al. 1997). However, our data also indicate that in spite of being at the same stage of the breeding cycle, male late breeders caught different prey compared to male early breeders. Notably, the frequency of Krefftichthys andersonni, which is the main species of the mesopelagic ichthyofauna at the end of summer, decreased. This species was replaced by Protomyctophum tenisoni, a prey more characteristic of the penguin diet in autumn and winter (Cherel et al. 1996). Late breeders seem to have greater difficulty foraging than early ones, as is the case of foraging in winter (Jouventin et al. 1994, Moore et al. 1999, Charrassin \& Bost 2001). Most King penguins forage at the Antarctic Polar Front during the incubation and brooding periods (Jouventin et al. 1994, Bost et al. 1997). During the austral summer, myctophid fish are mostly available at the Antarctic Polar Front, between the Subantarctic and Antarctic waters (Koubbi 1993). The summer 1995 to 1996 was marked by substantial mesoscale sea-warming with the early displacement of the Antarctic Polar Front causing an increase in the foraging trip duration of King penguins. In March 1996, the Antarctic Polar Front was $200 \mathrm{~km}$ farther south than usual. Changes in water mass positions might have induced a modification of the accessibility of the myctophid fishes. We therefore assume that the strategy of anticipating hatching by long-term food storage and conservation in the stomach while fasting evolved in response to these unpredictable variations of water mass positions, notably the Antarctic Polar Front, whose position has varied greatly in the past (Hall 1990, Bergstrom \& Chown 1999).

Acknowledgements. This work was supported by the Institut Français pour la Recherche et la Technologie Polaires (IFRTP) and the CNRS. We are very grateful to Gabriel Brézard, J. B. Charrassin, S. Drault, D. Gremillet, R. Groscolas, E. Mioskowski and E. Valentini for their help. The study was approved by the Ethical Committee of the IFRTP.

\section{LITERATURE CITED}

Barrat A (1976) Quelques aspects de la biologie et de l'écologie du Manchot Royal Aptenodytes patagonicus des îles Crozet. Com Nat Fr Rech Antarct 40:9-52

Barré H (1978) Energy metabolism of the King penguin chick
Aptenodytes patagonicus (J. F. Miller) during growth. J Physiol Paris 74:555-561

Begon M, Harper JL, Townsend CR (1986) Ecology: individuals, populations and communities. Blackwell Scientific Publications, Oxford

Bergstrom DM, Chown SL (1999) Life at the front: history, ecology and change on southern ocean islands. Trends Ecol Evol 14:472-473

Bost CA, Georges JY, Guinet C, Cherel Y and 6 others (1997) Foraging habitat and food intake of satellite-tracked king penguins during the austral summer at Crozet Archipelago. Mar Ecol Prog Ser 150:21-33

Charrassin JB, Bost CA (2001) Utilisation of the oceanic habitat by king penguin over the annual cycle. Mar Ecol Prog Ser 221:285-298

Charrassin JB, Bost CA, Pütz K, Lage J, Dahier T, Zorn T, Le Maho Y (1998) Foraging strategies of incubating and brooding King penguins Aptenodytes patagonicus. Oecologia 114:194-201

Cherel Y, Ridoux V (1992) Prey species and nutritive value of food fed during summer to king penguin Aptenodytes patagonica chicks at Possession Island, Crozet Archipelago. Ibis 134:118-127

Cherel Y, Mauget R, Lacroix A, Gilles J (1994) Seasonal and fasting-related changes in circulating gonadal steroids and prolactin in King penguins, Aptenodytes patagonicus. Physiol Zool 67:1154-1173

Cherel Y, Ridoux V, Rodhouse PG (1996) Fish and squid in the diet of king penguin chicks, Aptenodytes patagonicus, during winter at sub-antarctic Crozet Islands. Mar Biol 126:559-570

Clarke A, Prince PA (1976) The origin of stomach oil in marine birds: analyses of the stomach oil from six species of subantarctic procellariiform birds. J Exp Mar Biol Ecol 23: $15-30$

Costa DP (1991) Reproductive and foraging energetics of high latitude penguins, albatrosses and pinnipeds: implications for life history patterns. Am Zool 31:111-130

Croxall JP (1984) Seabirds. In: Laws RM (ed) Antarctic ecology, Vol 1. Academic Press, London, p 534-619

Davis LS, McCaffrey FT (1986) Survival analysis of eggs and chicks of Adélie penguins (Pygoscelis adeliae). Auk 103: 379-388

Davis LS, Miller GD (1990) Foraging patterns of Adelie penguins during the incubation period. In: Kerry KR, Hempel G (eds) Antarctic ecosystems ecological change and conservation. Springer-Verlag, Berlin, p 203-207

Davis LS, Cockrem JF, Miller GD, Court GS (1995) An incubation timer for seabirds: progesterone and its relationship to hatching in Adélie penguins. Emu 95:245-251

Descamps S, Gauthier-Clerc M, Gendner JP, Le Maho Y (2002) The annual breeding cycle of unbanded king penguins Aptenodytes patagonicus on Possession Island (Crozet). Avian Science 2 (in press)

Folch J, Lees M, Sloane-Stanley GH (1957) A simple method for the isolation and purification of total lipids from animal tissues. J Biol Chem 226:497-509

Gauthier-Clerc M, Le Maho Y, Clerquin Y, Drault S, Handrich $\mathrm{Y}$ (2000) Penguin fathers store food for their chicks. Nature 408:928-929

Gauthier-Clerc M, Le Maho Y, Gendner JP, Durant J, Handrich Y (2001) State-dependent decisions during courtship and incubation long-term fasts in king penguin. Anim Behav 62:661-669

Gendner JP, Gilles J, Challet E, Verdon C, Plumeré C, Reboud X, Handrich Y, Le Maho Y (1992) Automatic weighing and identification of breeding penguins. In: Priede IG, Swift 
SM (eds) 4th European international conference on wildlife telemetry. Ellis Horwood, Chichester, p 29-30

Gon O, Heemstra PC (1990) Fishes of the Southern Ocean. JLB Smith Institute of Ichthyology, Grahamstown

Hall KJ (1990) Quaternary glaciations in the southern ocean: sector $0^{\circ}$ long $-180^{\circ}$ long. Q Sci Rev 9:217-228

Handrich Y (1989) Incubation water loss in king penguin egg. I. Change in egg and brood pouch parameters. Physiol Zool 62:96-118

Hector JAL, Croxall JP, Follet BK (1986) Reproductive endocrinology of the wandering albatross Diomedea exulans in relation to biennial breeding and deferred sexual maturity. Ibis 128:9-22

Hunt GL, Schneider DC (1987) Scale-dependent processes in the physical and biological environment of marine birds. In: Croxall JP (ed) Seabirds: feeding biology and role in marine ecosystems. Cambridge University Press, Cambridge, $\mathrm{p} 7-41$

Isenmann P (1971) Contribution à l'éthologie et à l'écologie du manchot empereur (Aptenodytes forsteri Gray) à la colonie de Pointe Géologie (Terre Adélie). Oiseau Rev Fr Ornithol 41:9-64

Jackson S, Place AR (1989) Living off the fat of the sea: seabird digestion. Nuclear Active 41:38-41

Johnstone RM, Davis LS (1990) Incubation routines and foraging-trip regulation in the grey-faced petrel Pterodroma macroptera gouldi. Ibis 132:14-20

Jouventin P (1982) Visual and vocal signals in penguins, their evolution and adaptive characters. Verlag Paul Parey, Berlin

Jouventin P, Capdeville D, Cuénot-Chaillet F, Boiteau C (1994) Exploitation of pelagic resources by a non-flying seabird: satellite tracking of the King penguin throughout the breeding cycle. Mar Ecol Prog Ser 106:11-19

Kirkwood R, Robertson G (1997) Seasonal change in the foraging ecology of emperor penguins on the Mawson Coast, Antarctica. Mar Ecol Prog Ser 156:205-223

Kooyman GL, Cherel Y, Le Maho Y, Croxall JP, Thorson PH, Ridoux V, Kooyman CA (1992) Diving behaviour and energetics during foraging cycle in king penguins. Ecol Monogr 62:143-163

Koubbi P (1993) Influence of the frontal zones on ichthyoplankton and mesopelagic fish assemblages in the Crozet Basin (Indian sector of the Southern Ocean). Polar Biol 13: 557-564

Koudil M, Charrassin JB, Le Maho Y, Bost CA (2000) Seabirds as monitors of upper-ocean thermal structure: King penguins at the Antarctic Polar Front, east of Kerguelen sector. CR Acad Sci III-Vie 323:377-384

Le Maho Y, Gendner JP, Challet E, Bost CA and 5 others (1993) Undisturbed breeding penguins as indicators of changes in marine resources. Mar Ecol Prog Ser 95:1-6

Moore GJ, Robertson G, Wienecke B (1998) Food requirements of breeding king penguins at Heard Island and potential overlap with commercial fisheries. Polar Biol 20: 293-302

Moore GJ, Wienecke B, Robertson G (1999) Seasonal change in foraging areas and dive depths of breeding king penguins at Heard Island. Polar Biol 21:376-384

Editorial responsibility: Otto Kinne (Editor), Oldendorf/Luhe, Germany
Moore JK, Abbott MR, Richman JG (1999) Location and dynamics of the Antarctic Polar Front from satellite sea surface temperature data. J Geophys Res 104:3059-3073

Newsholme EA, Leech AR (1988) Biochemistry for the medical sciences. Wiley-Liss, New York

Olsson O, North AW (1997) Diet of the King penguin Aptenodytes patagonicus during three summers at South Georgia. Ibis 139:504-512

Park YH, Charriaud E, Fieux M (1998) Thermohaline structure of the Antarctic surface water/winter water in the Indian sector of the southern ocean. J Mar Syst 17:5-23

Peters G (1997) A new device for monitoring gastric $\mathrm{pH}$ in free-ranging animals. Am J Physiol 273:748-753

Peterson RG, White WB (1998) Slow oceanic teleconnections linking the Antarctic Circumpolar Wave with the tropical El Niño-Southern Oscillation. J Geophys Res 103:573-583

Prévost J (1961) Ecologie du Manchot empereur. Hermann, Paris

Prévost J, Vilter V (1963) Histologie de la sécretion oesophagienne du Manchot empereur. Proc Int Ornithol Congr 13:1085-1094

Pütz K, Bost CA (1994) Feeding behaviour of free-ranging King penguins Aptenodytes patagonicus. Ecology 75: 489-497

Reid BE, Bailey C (1966) The value of the yolk reserve in Adélie penguin chicks. Rec Dom Mus 5:185-193

Ricklefs RE (1983) Some considerations on the reproductive energetics of pelagic seabirds. Stud Avian Biol 8:84-94

Roby DR, Brink KL, Place AR (1989) Relative passage rates of lipid and aqueous digesta in the formation of stomach oils. Auk 106:303-313

Rodhouse PG, Olsson O, Anker-Nilssen P, Murray AWA (1998) Cephalopod predation by the King penguin Aptenodytes patagonicus from South Georgia. Mar Ecol Prog Ser 168:13-19

Schmidt-Nielsen K (1979) Animal physiology: adaptation and environment. Cambridge University Press, Cambridge

Siegel S, Castellan NJ (1988) Nonparametric statistics for the behavioral sciences. McGraw-Hill, New York

Stearns SC (1992) The evolution of life histories. Oxford University Press, Oxford

Stonehouse B (1960) The King penguin Aptenodytes patagonica of South Georgia. I. Breeding behaviour and development. Falkl Isl Depend Surv Sci Rep 23:1-81

Warham J, Watts R, Dainty RJ (1976) The composition, energy content and function of the stomach oils of petrels (Order Procellariiformes). J Exp Mar Biol Ecol 23:1-13

Weimerskirch H, Stahl JC, Jouventin P (1992) The breeding biology and population dynamics of King penguins Aptenodytes patagonica. Ibis 134:107-117

White WB, Peterson RG (1996) An Antarctic circumpolar wave in surface pressure, wind, temperature, and sea ice extent. Nature 380:699-702

Wilson RP (1984) An improved stomach pump for penguins and other seabirds. J Field Ornithol 55:109-112

Wilson RP, Ryan PG, Wilson MP (1989) Sharing food in the stomachs of seabirds between adult and chicks - a case for delayed gastric emptying. Comp Biochem Physiol 94A: 461-466

Submitted: August 23, 2001; Accepted: February 26, 2002

Proofs received from author(s): May 27, 2002 